\title{
Implementasi Operasi Tangkap Tangan Yang Dilakukan Komisi Pemberantasan Korupsi
}

\author{
Muhammad Alfin Saputra \\ Magister Hukum Universitas Islam Indonesia Yogyakarta Indonesia \\ Jln. Cik Di Tiro No. 1 Yogyakarta Indonesia \\ alfinsaputraa@ rocketmail.com
}

\begin{abstract}
The purpose of this study is to examine the implementation of hand arrest operations (OTT) carried out by the Corruption Eradication Commission (KPK) and whether such operations go in line with the concept of hand arrest in the Indonesian Criminal Procedure Code (KUHAP). This is a normative research which is supported by information obtained from various sources, by utilizing statutory and conceptual approaches, analyzed in a qualitative descriptive method. The results of this study conclude that the hand arrest operation carried out by the Corruption Eradication Commission is in fact very effective in ensnaring the perpetrators of corruption crimes as it provides a cristal clear view on the criminal act that occurred in order to identify the suspect.
\end{abstract}

Key Words: KPK; hand-catching operation; KUHAP

\begin{abstract}
Abstrak
Tujuan penelitian ini untuk mengkaji implementasi operasi tangkap tangan (OTT) yang dilakukan oleh Komisi Pemberantasan Korupsi (KPK) dan kesesuaian operasi tangkap tangan atas tindak pidana korupsi oleh Komisi Pemberantasan Korupsi dengan konsep tangkap tangan dalam KUHAP. Jenis penelitian ini adalah penelitian normatif yang didukung dengan keterangan yang diambil dari narasumber dengan menggunakan pendekatan perundang-undangan dan pendekatan konseptual serta menganalisisnya dengan menggunakan metode deskriptif kualitatif. Hasil penelitian ini menyimpulkan bahwa Operasi Tangkap Tangan yang dilakukan Komisi Pemberantasan Korupsi sangatlah efektif dalam menjerat pelaku tindak pidana korupsi karena membuat terang dan jelas suatu tindak pidana yang terjadi guna menemukan tersangkanya.
\end{abstract}

Kata-Kata Kunci: KPK; operasi tangkap tangan; KUHAP 


\section{Pendahuluan}

Tindak pidana korupsi merupakan tindak pidana terkait penggunaan kekuasaan atau jabatan seseorang untuk kepentingan pribadinya. ${ }^{1}$. Tindak pidana korupsi merupakan ancaman besar bagi Indonesia sampai saat ini. ${ }^{2}$ Kasus korupsi juga menjadi salah satu kategori dari kejahatan yang luar biasa (extra ordinary crime) karena telah mencuri harta negara dan memiskinkan rakyat untuk kepentingan pribadi maupun kelompok. Peningkatan kasus korupsi yang menyebabkan peningkatan jumlah kerugian uang negara dapat memberikan dampak buruk bagi kehidupan perekonomian bangsa dan negara. ${ }^{3}$

Dalam upaya pemberantasan kasus kejahatan luar biasa (extraordinary crime) tersebut diperlukan suatu tindakan yang bersifat luar biasa (extraordinary measures) pula. 4 Tindakan luar biasa yang dimaksud salah satunya dengan melakukan Operasi Tangkap Tangan atau selanjutnya disebut OTT. Tindakan ini dilakukan oleh penyidik Komisi Pemberantasan Korupsi (KPK).

Terkait dengan OTT, Pasal 12 Undang-Undang No. 30 Tahun 2002 tentang Komisi Pemberantasan Tindak Pidana Korupsi memberi kewenangan pada KPK untuk melakukan penyadapan dan merekam segala bentuk pembicaraan melalui media elektronik dalam upaya penyidikan untuk pemberantasan korupsi. Selanjutnya dalam UU No. 19 Tahun 2019 tentang Perubahan Kedua atas UU No. 30 Tahun 2002 proses permulaan terhadap upaya penyadapan tersebut harus atas persetujuan dari Dewan Pengawas. Yang mempunyai wewenang dalam melakukan hal tersebut adalah para penyelidik, penyidik dan penuntut yang merupakan pegawai KPK. Namun, UU No. 30 tahun 2002 telah mengalami suatu perubahan yang tercantum dalam UU No. 19 Tahun 2019 tentang Perubahan Kedua atas UU No. 30 Tahun 2002 tentang Komisi Pemberantasan Tindak Pidana Korupsi. Pasal 38 UU No. 19 Tahun 2019 tentang Perubahan Kedua atas UU No. 30 Tahun 2002 tentang Komisi Pemberantasan Tindak Pidana Korupsi menyatakan bahwa "Segala kewenangan yang berkaitan dengan penyelidikan, penyidikan, dan penuntutan yang diatur dalam Undang-Undang yang mengatur mengenai hukum acara pidana berlaku juga bagi penyelidik, penyidik dan

1 Romli Atmasasmita, Sekitar Masalah Korupsi Aspek Nasional dan Aspek Internasional, Mandar Maju, Bandung, 2004, hlm. 1

2 Achmad Zainuri, Akar Kultural Korupsi di Indonesia, Cahaya Baru Sawangan, Depok, 2007, hlm. 15

3 Yasmirah Mandasari Sarigih, Teguh Prasetyo, Jawade Hafidz, "Analisis Yuridis Kewenangan Komisi Pemberantasan Korupsi sebagai Penuntut Pelaku Tindak Pidana Korupsi, Unifikasi” Jurnal Ilmu Hukum, Universitas Kuningan, Jawa Barat, 2018, URL: https://journal.uniku.ac.id/index.php/unifikasi/article/view/ 763/622, diakses pada 7 September 2019

4 Ali Masyahar, 2009, Gaya Indonesia Menghadang Terorisme Sebuah Kritik Atas Kebijakan Hukum Pidana terhadap Tindak Pidana Terorisma di Indonesia, Mandar Maju, Bandung, hlm. 5. Fira Mubayyinah, "Legal Review of Indefinite Revocation of the Political Right to Hold Public Office Against Corruption Convicts", 2 (1) Prohpetic Law Review 90, 2019, 92-95. 
penuntut umum pada Komisi Pemberantasan Korupsi, kecuali ditentukan lain berdasarkan Undang-Undang ini."5 Kemudian di Pasal 39 Undang-Undang Nomor 30 Tahun 2002 disebutkan bahwa:

1. Penyelidikan, penyidikan, dan penuntutan tindak pidana korupsi dilakukan berdasarkan hukum acara pidana yang berlaku dan berdasarkan Undang-Undang Nomor 31 Tahun 1999 tentang Pemberantasan Tindak Pidana Korupsi sebagaimana telah diubah dengan Undang-Undang Nomor 20 Tahun 2001 tentang Perubahan atas Undang-Undang Nomor 31 Tahun 1999 tentang Pemberantasan Tindak Pidana Korupsi, kecuali ditentukan lain dalam UndangUndang ini.

2. Penyelidikan, penyidikan, dan penuntutan sebagaimana dimaksud pada ayat (1) dilaksanakan berdasarkan perintah dan bertindak untuk dan atas nama Komisi Pemberantasan Korupsi.

3. Penyelidik, penyidik, dan penuntut umum yang menjadi pegawai pada Komisi Pemberantasan Korupsi, diberhentikan sementara dari instansi kepolisian dan kejaksaan selama menjadi pegawai pada Komisi Pemberantasan Korupsi.

Berdasarkan kewenangan tersebut maka kewenangan OTT dalam tindak pidana korupsi oleh KPK dilakukan berdasarkan KUHAP dan UU Tipikor (UU No. 31 Tahun 1999 jo UU No. 20 Tahun 2001) kecuali yang ditentukan lain dalam Undang-Undang ini. Pengecualian yang dimaksud dalam UU No. 19 Tahun 2019 tentang KPK tersebut memberikan perbedaan kewenangan KPK dengan penegak hukum lainnya.

\section{Rumusan Masalah}

1. Bagaimana implementasi Operasi Tangkap Tangan (OTT) yang dilakukan oleh Komisi Pemberantasan Korupsi (KPK)?

2. Apakah Operasi Tangkap Tangan oleh Komisi Pemberantasan Korupsi sesuai dengan konsep tangkap tangan dalam KUHAP?

\section{Tujuan Penelitian}

1. Tujuan dari penelitian ini untuk mengkaji implementasi Operasi Tangkap Tangan yang dilakukan oleh Komisi Pemberantasan Korupsi (KPK).

2. Tujuan dari penelitian ini untuk mengkaji kesesuaian konsep Operasi Tangkap Tangan oleh Komisi Pemberantasan Korupsi sesuai dengan konsep tangkap tangan dalam KUHAP.

5 UU No. 19 Tahun 2019 tentang Perubahan Kedua atas UU No. 30 Tahun 2002 tentang Komisi Pemberantasan Tindak Pidana Korupsi 


\section{Metode Penelitian}

Penelitian mengenai implementasi Operasi Tangkap Tangan (OTT) yang dilakukan oleh Komisi Pemberantasan Korupsi (KPK) ini merupakan penelitian normatif. Penelitian normatif yaitu menganalisis terkait permasalahan hukum berdasarkan pada peraturan perundang-undangan yang berlaku. ${ }^{6}$ Penelitian hukum dengan metode normatif menitikberatkan pada penelitian kepustakaan guna memperoleh data sekunder sebagai data utamanya. ${ }^{7}$ Pendekatan yang digunakan di dalam penelitian hukum adalah pendekatan perundang-undangan (statute approach) dan pendekatan konseptual (conceptual approach). ${ }^{8}$ Pendekatan melalui aturan perundang-undangan (statute approach) dilakukan dengan menelaah semua peraturan perundang-undangan dan regulasi yang memiliki kerterkaitan dengan isu hukum yang sedang diteliti. Sedangkan pendekatan konseptual (conceptual approach) yaitu pendekatan yang ditelaah dari pandanganpandangan dan doktrin-doktrin yang berkembang di dalam ilmu hukum. ${ }^{9}$ Yang dijadikan sebagai bahan penelitian, yaitu: bahan hukum primer dan sekunder. Yang kemudian akan diolah, disusun secara sistematis sehingga diperoleh gambaran yang jelas dan lengkap tentang objek penelitian. ${ }^{10}$

\section{Hasil Penelitian dan Pembahasan}

\section{Implementasi Operasi Tangkap Tangan (OTT) yang dilakukan oleh Komisi Pemberantasan Korupsi (KPK)}

Salah satu upaya KPK dalam menangani kasus korupsi adalah dengan melakukan OTT. ${ }^{11}$ Istilah OTT berbeda dengan tertangkap tangan. Menurut Laica Marzuki, Pengajar Universitas Hasanuddin, Makassar, OTT tidak dikenal dalam Kitab Undang-Undang Hukum Acara Pidana (KUHAP). OTT adalah istilah yang mengandung makna kontradiksi atau berlawanan dan mengacaukan istilah hukum. ${ }^{12}$ Menurut Fahri Hamzah pelaksanaan OTT tidak menuntaskan persoalan

\footnotetext{
${ }^{6}$ Mukti Fajar ND dan Yulianto Achmad, Dualisme Penelitian Hukum Normatif dan Empiris, Pustaka Pelajar, Yogyakarta, 2010, hlm. 44

${ }^{7}$ M. Syamsudin, Operasionalisasi Penelitian Hukum, PT RajaGrafindo Persada, Jakarta, 2007, hlm. 25

8 Peter Mahmud Marzuki, Penelitian Hukum, Prenada Media Grup, Jakarta, 2011, hlm. 93

${ }^{9}$ Ibid., hlm. 93-95

${ }^{10}$ M. Syamsudin, Operasionalisasi Penelitian Hukum, PT RajaGrafindo Persada, Jakarta, 2007, hlm. 126

11 "Pencalonan Tidak Berdasarkan Integritas", Suara Pembaruan, 21 Februari 2020, dan "Pemberantasan Korupsi 2019: Jumlah OT"T Meningkat”, Suara Pembaruan, 28 April 2020.

12 Penjelasan Laica Marzuki sebagai Ahli, yang disampaikan di hadapan hakim tunggal I Wayan Karya dalam Sidang Praperadilan Irman Gusman melawan KPK di Pengadilan Negeri Jakarta Selatan, 27 Oktober 2016, Harian Haluan, 2 Februari 2017, "Laica Marzuki Jadi Saksi Ahli IG", 28 Oktober 2016, http://harianhaluan.com/news/detail/61394/istilah-ott-kacaukan-hukum-acara, diakses 2 April 2020
} 
korupsi di Indonesia. ${ }^{13}$ Demikian pula menurut Hibnu Nugroho, Guru Besar dari Universitas Jenderal Soedirman Purwokerto, yang menyatakan bahwa OTT adalah istilah yang tidak tepat dan tidak diatur dalam KUHAP. Adapun yang tepat adalah operasi penangkapan karena sebelumnya sudah didahului dan ditemukan bukti permulaan yang cukup. Dalam ilmu kriminalistik, tindakan tersebut merupakan bagian dari taktik pengungkapan kejahatan oleh penyidik. ${ }^{14}$

Terdapat banyak pro dan kontra terkait tindakan OTT oleh KPK ini. Pihak yang pro menyatakan bahwa OTT merupakan cara yang tepat untuk menangkap para koruptor karena tidak memerlukan alur birokrasi yang panjang dan menghasilkan barang bukti yang konkret. Disisi lain pihak yang kontra menganggap pelaksanaan OTT menyalahi aturan dalam KUHP. Disebut menyalahi karena terminologi dalam KUHP adalah "tertangkap tangan" dan bukan "operasi tangkap tangan" seperti yang selama ini dilakukan oleh KPK. Terlebih, mekanisme penjebakan yang sering kali digunakan sebagai rangkaian operasi tangkap tangan tidak memiliki dasar hukum yang jelas dalam konteks pemberantasan korupsi. ${ }^{15}$

Dalam sistem hukum acara pidana, pejabat tertentu diberi kewenangan untuk melakukan pembatasan terhadap kebebasan dan kemerdekaan seseorang atas alasan telah melakukan tindak pidana. KUHAP menentukan beberapa tindakan atau upaya paksa yang dapat dilakukan sehubungan dengan terjadinya tindak pidana yang kemudian memberikan wewenang kepada penyidik untuk mengurangi kebebasan seseorang. Namun penggunaan wewenang ini harus tetap berlandaskan hukum dan prinsip- prinsip yang menjunjung tinggi harkat martabat manusia dan menjamin keseimbangan antara perlindungan kepentingan tersangka di satu pihak dan kepentingan masyarakat luas juga kepentingan umum di lain pihak. ${ }^{16}$

Wewenang yang diberikan pada penyidik dalam membatasi kebebasan seseorang tersebut dapat dilakukan dalam bentuk tindakan penangkapan, penahanan, penyitaan, dan penggeledahan. Penangkapan adalah suatu tindakan penyidik berupa pengekangan sementara waktu kebebasan tersangka atau terdakwa apabila terdapat cukup bukti guna kepentingan penyidikan atau penuntutan dan /atau peradilan dalam hal serta menurut cara yang diatur dalam

13 Fahri Hamzah, "Sistematika Pemberantasan Korupsi”, Makalah disampaikan dalam acara Seminar Nasional dengan tema "Pemetaan Korupsi di Lembaga Eksekutif, Legislatif, dan Yudikatif: Strategi Pencegahan dan Penindakannya", diselenggarakan oleh Pusat Penelitian Badan Keahlian DPR RI, 30 Maret 2020, hlm. 1-6.

14 "Memahami Istilah Operasi Tangkap Tangan di Kasus Patrialis Akbar", 30 Januari 2017, https:// news.detik.com/berita/d-3409476/memahami-istilah-operasi-tangkap-tangan-di-kasus-patrialis-akbar, diakses 20 Maret 2020.

${ }^{15}$ K. Lutfiasandh, Konsep Operasi Tangkap Tangan Tindak Pidana Korupsi Oleh Komisi Pemberantasan Korupsi, Universitas Airlangga, 2019, hlm. 57

${ }^{16}$ Ramelan, Hukum Acara Pidana (Teori dan Implementasi), Sumber Ilmu Jaya, Jakarta, 2006, hlm. 84 
undang-undang ini. ${ }^{17}$ Pejabat yang berwenang melakukan penangkapan adalah penyelidik atas perintah penyidik yang melakukan penangkapan untuk kepentingan penyidikan dan / atau penyidik dan penyidik pembantu yang melakukan penangkapan untuk kepentingan penyidikan. ${ }^{18}$

Pasal 117 KUHAP menentukan bahwa penyelidik dan penyidik/penyidik pembantu memiliki kewenangan melakukan penangkapan terhadap seseorang yang diduga keras melakukan tindak pidana dan harus berdasarkan bukti permulaan yang cukup. ${ }^{19}$ Ketentuan ini menunjukkan bahwa perintah penangkapan tidak dapat dilakukan sewenang-wenang. Penangkapan ditujukan kepada mereka yang benar-benar melakukan tindak pidana berdasar bukti permulaan yang cukup. Mengenai "bukti permulaan yang cukup" dijelaskan dalam penjelasan Pasal 17 KUHAP yaitu bahwa bukti permulaan ditujukan untuk menduga adanya tindak pidana sesuai dengan bunyi Pasal 1 angka 14 KUHAP. ${ }^{20}$ Pengaturan tentang bukti permulaan tersebut belum jelas sehingga dalam praktek biasanya bukti permulaan cukup didasarkan pada keterangan saksi dan didukung pula dengan alat bukti lain seperti alat bukti petunjuk berupa barang bukti dan sebagainya. ${ }^{21}$

Ketidakjelasan makna bukti permulaan yang cukup dalam penangkapan mendapat titik terang melalui Putusan Mahkamah Konstitusi (MK) Nomor 21/PUU-XII/2014. Putusan ini menyatakan tentang "bukti permulaan", "bukti permulaan yang cukup", dan "bukti yang cukup" sebagaimana ditentukan dalam Pasal 1 angka 14, Pasal 17, dan Pasal 21 ayat (1) KUHAP harus ditafsirkan dengan sekurang-kurangnya dua alat bukti yang termuat dalam Pasal 184 KUHAP.22 Adapun alat bukti yang sah menurut Pasal 184 ayat (1) KUHAP ialah keterangan saksi; keterangan ahli; surat; petunjuk; dan keterangan terdakwa. Dalam putusan tersebut, Mahkamah Konstitusi menilai bahwa KUHAP tidak memberi penjelasan mengenai batasan jumlah (alat bukti) dari frasa "bukti permulaan", "bukti permulaan yang cukup", dan "bukti yang cukup". Mahkamah Konstitusi menganggap syarat minimum dengan dua alat bukti dan pemeriksaan calon tersangka merupakan bentuk transparansi dan perlindungan hak asasi seseorang. Hal ini untuk menghindari kesewenang-wenangan oleh penyidik terutama dalam menentukan tentang kecukupan bukti permulaan.

\footnotetext{
17 Lihat Pasal 1 angka 20 KUHAP.

18 Lihat Pasal 16 KUHAP

${ }^{19}$ Lihat Pasal 17 KUHAP

20 Penjelasan Pasal 17 KUHAP

${ }^{21}$ Ramelan, Op. Cit., hlm. 85

22 Putusan MK Nomor 21/PUU-XII/2014 Mengenai Permohonan Pengujian UU No. 8 Tahun 1981 tentang Hukum Acara Pidana terhadap Undang-Undang Dasar Negara Republik Indonesia Tahun 1945.
} 
Sementara itu, OTT adalah istilah KPK untuk menangkap basah seseorang yang diduga sebagai pelaku tindak pidana korupsi. Sebuah operasi yang bersifat rahasia, terukur dan jarang target operasinya yang dapat selamat dari tuduhan karena didasari dengan proses yang panjang ketika KPK "mengendus" adanya indikasi tindak pidana korupsi. ${ }^{23}$ Istilah OTT baru muncul dalam Peraturan Presiden Republik Indonesia (Perpres) No. 87 Tahun 2016 tentang Satuan Tugas Sapu Bersih Pungutan Liar. Perpres tersebut membentuk Satuan Tugas Sapu Bersih Pungutan Liar yang selanjutnya disebut sebagai Satgas Saber Pungli yang berkedudukan dibawah dan serta bertanggung jawab kepada Presiden. ${ }^{24}$ Dalam melaksanakan tugas dan fungsinya, Satgas Saber Pungli mempunyai sejumlah wewenang, salah satunya adalah melakukan operasi tangkap tangan.

Dalam melakukan OTT ada dua teknik yang digunakan KPK yaitu penyadapan dan penjebakan. ${ }^{25}$ Pertimbangan hakim dalam beberapa putusan Mahkamah Konstitusi terkait penyadapan antara lain mengatakan bahwa kewenangan tersebut dalam Pasal 12 ayat (1) huruf a UU KPK bertentangan dengan Pasal 28G ayat (1) Undang-Undang Dasar Negara Republik Indonesia Tahun 1945 (UUD Tahun 1945), yang menyebutkan bahwa "Setiap orang berhak atas perlindungan diri pribadi, keluarga, kehormatan, martabat, dan harta benda yang di bawah kekuasaannya, serta berhak atas rasa aman dan perlindungan dari rasa ketakutan untuk berbuat atau tidak berbuat sesuatu yang merupakan hak asasi." Namun, MK menjelaskan hak privasi bukanlah bagian dari hak-hak yang tidak dapat dikurangi dalam keadaan apapun (nonderogable rights) sehingga negara dapat melakukan pembatasan terhadap pelaksanaan hak-hak tersebut dengan menggunakan Undang-Undang, sebagaimana diatur dalam Pasal 28J ayat (2) UUD Tahun 1945. Mahkamah Konstitusi mengamanatkan untuk membentuk satu aturan tentang mekanisme dan prosedur penyadapan yang berisi syaratsyarat:

1. Adanya otoritas resmi yang ditunjuk dalam UU untuk memberikan izin penyadapan, menurut Undang-Undang, KPK diberikan kewenangan untuk melakukan penyadapan;

2. Adanya jaminan jangka waktu yang pasti dalam melakukan penyadapan;

3. Pembatasan penanganan materi hasil penyadapan; dan

4. Pembatasan mengenai orang yang dapat mengakses penyadapan.

\footnotetext{
${ }^{23}$ Fatimah Asyari, "Operasi Tangkap Tangan di Pusat dan Daerah untuk Meraih WTP Terkait Masalah Pelanggaran Hukum”, Jurnal Legalitas, Vol. 2 No. 1, Juni 2017, hlm. 57-66

${ }^{24}$ Pasal 1 Perpres Nomor 87 Tahun 2016.

25 “Operasi Tangkap Tangan oleh KPK", 1 Februari 2017, https://www.nyatnyut.com/2017/02/01/ operasi-tangkap-tangan-oleh-kpk/, diakses 14 April 2020
} 
KUHAP telah memberikan dasar hukum untuk melakukan Operasi Tangkap Tangan yang ditentukan dalam Pasal 1 butir 19 KUHAP yaitu "Tertangkap tangan adalah tertangkapnya seorang pada waktu sedang melakukan tindak pidana, atau dengan segera sesudah beberapa saat tindak pidana itu dilakukan, atau sesaat kemudian diserukan oleh khalayak ramai sebagai orang yang melakukannya, atau apabila sesaat kemudian padanya ditemukan benda yang diduga keras telah dipergunakan untuk melakukan tindak pidana itu yang menunjukkan bahwa ia adalah pelakunya atau turut melakukan atau membantu melakukan tindak pidana itu."

Menurut Eddy OS Hiariej, dalam konteks pembuktian di peradilan, buktibukti diperoleh melalui Operasi Tangkap Tangan sangatlah jelas, akurat dan pasti. Operasi Tangkap Tangan sangat efektif untuk membuktikan kejahatankejahatan yang sulit dicari pembuktiannya termasuk kejahatan korupsi karena bukti tersebut langsung dapat diperoleh. Pembuktian perkara pidana sesuai postulat In Criminalibus Probantiones Bedent Esse Luce Clariores yang berarti bahwa dalam perkara-perkara pidana bukti bukti yang diperoleh haruslah lebih terang daripada cahaya, sebab melalui Operasi Tangkap Tangan langsung diperoleh bukti yang jelas, terang, dan akurat serta tidak terbantahkan bukan hanya berdasar persangkaan saja. Operasi Tangkap Tangan sudah pasti didahului oleh serangkaian tindakan penyadapan yang telah dilakukan dalam jangka waktu tertentu. Hasil penyadapan pada dasarnya merupakan bukti permulaan terjadinya suatu tindak pidana jika antara bukti yang satu dan bukti yang lain terdapat kesesuaian (Corroborating Evidence). Artinya, perkara tersebut sudah siap diproses secara pidana karena memiliki minimal dua alat bukti. Dalam konteks kekuatan pembuktian, Operasi Tangkap Tangan dapat dikatakan memenuhi pembuktian sempurna (Probatio Plena) yang berarti bukti tersebut tidak lagi menimbulkan keraguan-raguan mengenai keterlibatan pelaku dalam suatu kejahatan. Kendatipun demikian, hakim dalam perkara pidana tidak terikat secara mutlak terhadap satu pun alat bukti, akan tetapi Operasi Tangkap Tangan paling tidak dapat menghilangkan keraguan tersebut. ${ }^{26}$

Menurut B Scheltema, ciri dari negara hukum adalah adanya pengakuan penghormatan dan perlindungan hak asasi manusia yang berakar dari penghormatan martabat manusia (human dignity) dan asas kepastian hukum (the rule of law prinsiple). Terkait dengan hal tersebut pengaturan dan pelaksanaan mengenai penyadapan tidak boleh melanggar hak asasi manusia dan harus diatur terlebih dahulu dalam peraturan perundang-undangan sehingga memberikan

26 Eddy OS Hiariej "Operasi Tangkap Tangan" https://nasional.kompas.com/read/2013/10 /07/1116524/Operasi.Tangkap.Tangan, pada 02 April 2020 pukul 20.00 WIB 
kepastian hukum. ${ }^{27}$ Berdasarkan pendapat tersebut, maka diperlukan adanya peraturan pelaksana terhadap penyadapan yang termuat dalam Undang-Undang terkait kewenangan yang dilakukan oleh KPK. Dengan adanya peraturan tersebut pelaksanaan tindak penyadapan yang menjamin kelangsungan penegakan hukum (law enforcement) dapat sekaligus memberikan jaminan pada hak-hak asasi manusia (guarantee the rights). Hal ini untuk menghindari penyalahgunaan kepentingan selain kepentingan penegakan hukum yang mengakibatkan terjadi pelanggaran hak asasi. Penyadapan berakibat terjadinya pengurangan hak asasi terhadap personaliti yang menjadi subjek yang disadap tersebut ${ }^{28}$ oleh karena itu tindakan tersebut harus dipastikan dalam koridor yang tidak melanggar hak asasi yang bersangkutan.

Pada dasarnya seluruh kegiatan penanganan hukum terkait perkara pidana korupsi sama halnya dengan perkara pidana umum, yaitu berupa kegiatan yang terkait pembuktian atau kegiatan untuk membuktikan. Mencari bukti yang dimaksud sesungguhnya ialah mencari suatu alat bukti karena bukti tersebut hanya dapat diperoleh dari alat bukti termasuk barang bukti. Ditinjau dari peraturan perundang-undangan, terkait alat bukti yang sah dan boleh dipergunakan untuk proses pembuktian telah diatur di dalam Pasal 184 ayat (1) KUHAP, yaitu: Keterangan saksi; Keterangan ahli; Surat; Petunjuk; dan Keterangan terdakwa.

\section{Kesesuaian Konsep Operasi Tangkap Tangan oleh Komisi Pemberantasan Korupsi dengan Konsep Tangkap Tangan dalam KUHAP}

Pasal 12 Undang-Undang KPK secara eksplisit menyatakan "Dalam melaksanakan penyelidikan, penyidikan dan penuntutan sebagaimana dimaksud dalam Pasal 6 huruf c, Komisi Pemberantasan Korupsi berwenang a) melakukan penyadapan dan merekam pembicaraan...." Ketentuan tersebut secara expressive verbis membolehkan KPK menyadap dan merekam pembicaraan dalam penyelidikan. Artinya, penyadapan diperbolehkan untuk menentukan ada tidaknya tindak pidana sebagaimana yang dijelaskan dalam definisi penyelidikan dan yang dilakukan oleh KPK adalah suatu proses atau upaya pengumpulan bukti terkait informasi yang telah diperoleh melalui hasil penyadapan. Dalam pelaksanaan OTT, apabila KPK sedang melakukan OTT dan uang suap atau objek suap sudah berada di tangan terduga, maka yang terjadi adalah delik selesai. Namun, bilamana uang suap atau objek suap tersebut belum berada di tangan

${ }^{27}$ Kristian dan Yopi Gunawan, Sekelumit tentang Penyadapan dalam Hukum Positif di Indonesia, Nuansa Aulia, Bandung, 2013, hlm. 41

28 Trias Yuliana Dewi, dkk., Naskah Akademik Rancangan Undang-Undang tentang Penyadapan, Tim Legislative Drafting, Universitas Katolik Parahyangan (UNPAR), 2010, hlm. 9 
terduga, maka yang terjadi adalah percobaan terhenti. Dengan demikian yang menghubungkan antara tindakan OTT sebagai upaya hukum yang dilakukan oleh KPK dan delik percobaan bukanlah suatu bentuk analogi antara tertangkap tangan dan percobaan melainkan menghubungkan antara keadaan orang tertangkap tangan dengan delik percobaan..$^{29}$

KPK dalam hal ini sebagai lembaga yang berwenang dalam pemberantasan tindak pidana korupsi, dalam proses pelaksanaan tugas serta wewenangnya telah mengalami banyak perubahan dengan dibentuknya organ baru dalam upaya pemberantasan korupsi yang dilakukan oleh KPK yakni Dewan Pengawas. Kedudukan dari Dewan Pengawas ini menurut penulis bukanlah bagian dari organ yang secara struktural berada di dalam Criminal Justice System (penyelidik/penyidik, penuntut umum, hakim). Akan tetapi, Dewan Pengawas ini diberi supervisi terkait kewenangan penuh dalam proses pemidanan yang dilakukan oleh organ-organ di dalam criminal justice system tersebut.

\section{Penutup}

Berdasarkan pembahasan yang telah diuraikan di atas, maka kesimpulan yang dapat diambil sebagai berikut. Pertama, OTT yang dilakukan oleh KPK tidak memiliki aturan yang terkait dalam KUHAP maupun UU KPK. Namun, OTT yang merupakan suatu bentuk upaya dalam pemberantasan korupsi sebagai permulaan ialah melakukan upaya penyadapan untuk mendapatkan bukti permulaan telah diatur secara eksplisit dalam Pasal 12 ayat (1) huruf a UU KPK dan Pasal 50 UU No. 7 Tahun 2006 yang meratifikasi konvensi PBB Anti Korupsi yang jelas membolehkan melakukan pengamatan terhadap komunikasi elektronik, juga boleh melakukan undercover agent yang didalamnya termasuk delivery control. Dalam upaya pemberantasan tindak pidana korupsi, OTT adalah bentuk kewenangan yang diberikan secara sah oleh undang-undang yang diawali dengan proses penyadapan melalui persetujuan Dewan Pengawas. Dalam hal ini Dewan Pengawas yang memiliki kewenangan dalam mengawasi tugas dan wewenang KPK adalah suatu bentuk redefinisi terhadap upaya-upaya KPK dalam memberantas tindak pidana korupsi agar memiliki legitimasi dalam pelaksanaannya.

Kedua, konsep OTT dengan konsep tangkap tangan dalam KUHAP berbeda dengan alasan bahwa pelaksanaan operasi tangkap tangan penyidik KPK tidak langsung mendapati seorang yang melakukan suatu kejahatan pada saat

${ }^{29}$ Edward Omar Sharif Hiariej, "Legalitas OTT KPK", Guru Besar Fakultas Hukum Universitas Gadjah Mada, Artikel ini terbit di harian Sindo edisi 4 Maret 2020 
melakukan kejahatan tersebut atau sesaat setelahnya. Namun dalam OTT ini lebih sebagai upaya untuk memulai pemberantasan korupsi yang didasarkan pada laporan terlebih dulu. Dengan adanya laporan makan akan ditindaklanjuti dengan pengintaian melalui penyadapan ataupun penjebakan. Setelah itu barulah KPK melakukan sebuah upaya OTT untuk melakukan penangkapan terhadap pelaku.

Atas dasar tersebut, maka saran yang dapat diberikan adalah sebagai berikut. Pertama, Hendaknya pembuat Undang-Undang segera merumuskan mengenai pengertian dari OTT yang menjadi kewenangan KPK agar upaya pemberantasan korupsi mempunyai dasar legitimasi. Kedua, Komisi Pemberantasan Korupsi hendaknya segera menerbitkan petunjuk Teknis tentang bagimana tata cara para penyidik di KPK dalam melaksanakan tugasnya, termasuk di dalamnya tentang petunjuk untuk melaksanakan OTT.

\section{Daftar Pustaka}

\section{Buku}

Atmasasmita, Romli, Sekitar Masalah Korupsi Aspek Nasional dan Aspek Internasional, Mandar Maju, Bandung, 2004.

Danil, Elwi, Korupsi Konsep, Tindak Pidana, dan Pemberantasannya, PT RajaGrafindo Persada, Jakarta, 2012.

Fajar, Mukti dan Yulianto Achmad, Dualisme Penelitian Hukum Normatif dan Empiris,: Pustaka Pelajar, Yogyakarta, 2010.

Kristian dan Yopi Gunawan, Sekelumit tentang Penyadapan dalam Hukum Positif di Indonesia, Nuansa Aulia, Bandung, 2013.

M. Syamsudin, Operasionalisasi Penelitian Hukum, PT RajaGrafindo Persada, Jakarta, 2007.

Marzuki, Peter Mahmud, Penelitian Hukum, Prenada Media Grup, Jakarta, 2011.

Masyahar, Ali, Gaya Indonesia Menghadang Terorisme Sebuah Kritik Atas Kebijakan Hukum Pidana terhadap Tindak Pidana Terorisma di Indonesia, Mandar Maju, Bandung, 2009.

Mulyadi, Lilik, Pembalikan Beban Pembuktian Tindak Pidana Korupsi, Alumni, 2011, Bandung, 2013.

Ramelan, Hukum Acara Pidana (Teori dan Implementasi), Sumber Ilmu Jaya, Jakarta, 2006.

Rohim, Modus Operandi Tindak Pidana Korupsi, Pena Multi Media, Jakarta, 2008.

Zainuri, Achmad, Akar Kultural Korupsi di Indonesia, Cahaya Baru Sawangan, Depok, 2007.

\section{Peraturan Perundang-undangan}

UU No. 19 Tahun 2019 tentang Perubahan Kedua atas UU No. 30 Tahun 2002 tentang Komisi Pemberantasan Tindak Pidana Korupsi 
Pasal 1 angka 20 KUHAP

Pasal 16 KUHAP

Pasal 17 KUHAP

Penjelasan Pasal 17 KUHAP

Pasal 1 Perpres Nomor 87 Tahun 2016

Putusan MK Nomor 21/PUU-XII/2014 Mengenai Permohonan Pengujian UU No. 8 Tahun 1981 tentang Hukum Acara Pidana terhadap Undang-Undang Dasar Negara Republik Indonesia Tahun 1945

\section{Makalah/Jurnal/Media Massa}

Edward Omar Sharif Hiariej, "Legalitas OTT KPK", Guru Besar Fakultas Hukum Universitas Gadjah Mada, Artikel ini terbit di harian Sindo edisi 4 Maret 2020

Ilham Rian Pratama, 2019, "KPK Beberkan Kronologi OTT di Yogyakarta, Plastik Hitam Berisi Uang Rp. 110 Juta Disita dari Jaksa", dalam www.tribunnews.com, diakses 7 September 2019

Eddy OS Hiariej "Operasi Tangkap Tangan" https://nasional.kompas.com/ $\mathrm{read} / 2013 / 10 / 07 / 1116524 /$ Operasi.Tangkap.Tangan, pada 02 April 2020 pukul 20.00 WIB

Fahri Hamzah, 2017, "Sistematika Pemberantasan Korupsi", Makalah disampaikan dalam acara Seminar Nasional dengan tema "Pemetaan Korupsi di Lembaga Eksekutif, Legislatif, dan Yudikatif: Strategi Pencegahan dan Penindakannya", diselenggarakan oleh Pusat Penelitian Badan Keahlian DPR RI, 30 Maret 2020.

Fatimah Asyari, “Operasi Tangkap Tangan di Pusat dan Daerah untuk Meraih WTP Terkait Masalah Pelanggaran Hukum", Jurnal Legalitas, Vol. 2 No.1, Juni 2017, hl. 57-66.

Fira Mubayyinah, "Legal Review of Indefinite Revocation of the Political Right to Hold Public Office Against Corruption Convicts", 2 (1) Prohpetic Law Review 90, 2019.

Modus Kian Canggih", Kompas, 20 Februari 2020.

"Pencalonan Tidak Berdasarkan Integritas", Suara Pembaruan, 21 Februari 2020, dan "Pemberantasan Korupsi 2019: Jumlah OTT Meningkat", Suara Pembaruan, 28 April 2020.

K. Lutfiasandh, Konsep Operasi Tangkap Tangan Tindak Pidana Korupsi Oleh Komisi Pemberantasan Korupsi, Universitas Airlangga, 2019.

Philipus M. Hadjon, “Dasar Argumentasi Hukum dan Legal Opinion (Legal Memo)", Makalah Pelatihan Argumentasi Hukum Fakultas Hukum Universitas Airlangga, 18 Juni 2004

Trias Yuliana Dewi, dkk., Naskah Akademik Rancangan Undang-Undang tentang Penyadapan, Tim Legislative Drafting, Universitas Katolik Parahyangan (UNPAR), 2010 
Yasmirah Mandasari Sarigih, Teguh Prasetyo, Jawade Hafidz, 2018, “Analisis Yuridis Kewenangan Komisi Pemberantasan Korupsi sebagai Penuntut Pelaku Tindak Pidana Korupsi", Unifikasi: Jurnal Ilmu Hukum, Universitas Kuningan, Jawa Barat, URL: https://journal.uniku.ac.id/index.php/ unifikasi/article/view/763/622, diakses pada tanggal 7 September 2019

"Memahami Istilah Operasi Tangkap Tangan di Kasus Patrialis Akbar", 30 Januari 2017, https://news.detik.com/berita/d-3409476/memahamiistilah-operasi-tangkap-tangan-di-kasus-patrialis-akbar, diakses tanggal 20 Maret 2020

"Operasi Tangkap Tangan oleh KPK", 1 Februari 2017, https:/ / www.nyatnyut.com/2017/02/01/operasi-tangkap-tangan-olehkpk/, diakses 14 April 2020

Penjelasan Laica Marzuki sebagai Ahli, yang disampaikan di hadapan hakim tunggal I Wayan Karya dalam Sidang Praperadilan Irman Gusman melawan KPK di Pengadilan Negeri Jakarta Selatan, 27 Oktober 2016, Harian Haluan, 2 Februari 2017, “Laica Marzuki Jadi Saksi Ahli IG”, 28 Oktober 2016, http://harianhaluan.com/news/detail/61394/istilah-ottkacaukan-hukum-acara, diakses 2 April 2020 